\title{
SECURING HUMANITY
}

\section{- SITUATING ‘HUMAN SECURITY’ AS CONCEPT AND DISCOURSE}

\author{
Des Gasper \\ Institute of Social Studies, The Hague \\ Prefinal version of a paper that appeared in 2005 in the Journal of Human Development, \\ 6(2), pp. 221-245.
}

\begin{abstract}
The label 'human security' (HS) has attracted much attention since the 1994 Human Development Report, but there are numerous conflicting definitions and agendas and widespread scepticism. The Ogata-Sen Commission report Human Security Now has proposed a unified yet flexible definition and agenda. This paper specifies the Human Security Now concept as the intersection of: a concern with reasoned freedoms; a focus on basic needs; and a concern for stability as well as levels in key human development dimensions. Second, it specifies other elements of this human security discourse: a normative focus on individuals' lives and insistence on basic rights for all; and an explanatory agenda that stresses the nexus between freedom from want and indignity and freedom from fear. Third, it clarifies where the HS discourse repeats the Basic Human Needs conception and where it adds, and shows the consistency of the human security, human needs and human rights languages. Fourth, it specifies the types of intellectual 'boundary work' which the concept and discourse attempt: mobilizing attention and concern, connecting explanatory and normative agendas, and linking diverse intellectual and policy communities. Lastly, it assesses HS as a boundary concept, including the particular label chosen, and diagnoses the threats as well as opportunities implicit in security language.
\end{abstract}

Acknowledgements - My thanks for their helpful comments to Sabina Alkire, Asuncion Lera St. Clair, Ian Gough, Taylor Owen, Frances Stewart and two anonymous reviewers. 


\section{Introduction}

During the 1990s we became familiar with the insightful, liberating new languages of 'human development' and capability. We learnt to distinguish Nussbaum's 'capabilities approach' from Sen's 'capability approach'. We tried to digest how these related to, subsumed or situated older approaches, such as economists' focus especially since the 1940s on income and national product, and the multidisciplinary focus on basic needs, prominent in the 1960s to mid 1980s. We fought to keep up as approaches with new languages kept emerging and evolving. After Mahbub ul Haq's visionary pen had steadily widened the concept of 'human development', Amartya Sen proffered an encompassing synthesis through an augmented language of freedom(s). And how, asked next the Human Development Report (HDR) of 2000, does 'human development' relate to the language of human rights, which dates from at least the $17^{\text {th }}$ century? - perhaps, it suggested, as a justification of rights, while human rights language offers an essential format in policy operationalization.

Haq's final brainchild and legacy, with us since especially the $H D R$ of 1994, is an expansive concept of 'human security'. This highlights a distinction between the security of states and the security of persons, and re-visions the latter as not merely the physical safety of individuals but their ability to secure and hold basic goods. It is proposed as a partner, rather than component, of 'human development'; or sometimes even as its container, perhaps the biggest Russian doll of all. The concept has acquired wider prominence through the Commission on Human Security (also known as the Ogata-Sen commission) report of 2003, Human Security Now.

This paper does not offer another survey of the substantive concerns encompassed by the language of human security (see instead the July 2003 issue of this journal). It does not for example investigate linkages between physical security and other forms of security. Instead it maps the increasingly complex and sometimes confused field of concepts and usages, to help to place 'human security' in meaningful context, and to clarify how it relates to 'human development' and what it adds. I will examine the interrelations amongst three generations of concepts: relatively longstanding notions such as 'needs' and 'human rights'; concepts from the 1970s and 1980s such as basic needs, 
'capability' and 'human development' (HD); and the 1990s ideas of 'human security' (HS), especially as reformulated in Human Security Now and other recent work.

The first section investigates the content of the human security concept. It compares a number of interpretations or aspects, and clarifies and endorses the formulation in Human Security Now. It recognizes too a human security discourse that is broader than simply a single concept. The second section examines how far that discourse says anything new, or merely re-packages the basic human needs approach, of which Haq was one exponent. Is it only old wine in a new bottle? I will show instead how it synthesises concerns from basic needs, human development, and human rights.

Extending the metaphor, the human security concept is the bottle, the container for a discourse. The first section looks at the bottle - the concept - and the second section at the wine, the discourse. The third section then considers the impact of the entire 'package' of wine, bottle and 'label' (the words 'human security' that are chosen to present the wine), for which specific roles. Each section relies on the previous one(s). The third question, of how effective is the entire package, is the most difficult one; it is perhaps too soon to answer, but important to pose. The firmer conclusions of the paper will come from the first two sections, on the content and defensible scope of the concept and the degree of novelty of the discourse.

\section{1 - What is 'Human Security'? The Concept and the Discourse}

The Pakistani development leader and thinker, Mahbub ul Haq, championed the concept of 'human security' as a supplement to his 'human development' concept in the 1993 Human Development Report, the fourth in the series, and then at length and with considerable impact in the 1994 Report. This added six types of security to a conventional concern with security from physical violence: income security, food security, health security, environmental security, community/identity security, and security of political freedoms. Just as 'human development' for him was more than a humanizing addition of health and education concerns to economic growth, so 'human security' meant securing what is humanly central, not only humanizing an existing state security discourse by a concern for the physical security of persons. 
Why did Haq add another large concept so soon, and in a way that diverted attention and produced confusion through its considerable apparent overlap with the human development concept? One finds still a wide variety of usages, even presented in Human Security Now (especially chapter 1). Human security literature often reads like an uneasy merger of human development and peace themes, via the bridge of the term 'security': 'human security joins the main agenda items of peace, security and development' (Commission on Human Security, 2003, p.4). In fact the HS discourse does more.

The confusion is remediable; and rather than being 'diverted', attention has been redirected to where it is required, by restoring a prioritizing notion within the enormous canvas of HD discourse. HS language in effect revives a basic needs notion, under a new label. The particular label chosen, 'security', perhaps reflected Haq's location in the United Nations system. Haq was a leader rather than a systematizer, so one should not seek a tidy, let alone explicit and elaborate, system in his own writings. Yet one can try to reconstruct the set of insights, hypotheses and intuitions which inspired this creative thinker and doer during the final, remarkably successful, decade of his life.

A first answer given to the question why we need a concept of human security is to say that HS concerns the stability of the effective, i.e. attainable, valued opportunities which are the currency of evaluation in Sen's capability approach. In particular it concerns 'downside risks' (e.g. Sen, 2003). But 'human security' could then concern also the degree of stability with which the super-rich possess super-riches. Clearly Sen intends something more here by 'security' than merely stability; such as removal of intolerable risks. An $\mathrm{x} \%$ fall in income for a rich person and for a poor person are not the same experience. His phrase 'downturn with security', introduced to partner the conventional aspiration of 'growth with equity', might not avoid this danger if security is equated to stability. We require two augmented phrases, 'growth with equity and security' and 'downturn with equity and security', unless we could assume that equity entails security. In fact (distributive) equity concerns fair distribution of whatever is present, including risks, and so does not ensure security. Nor does security entail equity of distribution. 
This first answer focuses only on the noun 'security' and neglects the adjective 'human'. It is an answer from the side of HD discourse: the HS concept is seen as an addition that concerns stability of HD as opposed to its level or trend.

A second proposed answer is that 'human security' concerns 'freedom from fear' in addition to 'freedom from want', to use the terms of the US Secretary of State in 1945 (cited by Haq, 1999, p. 190). This can be construed as addition of physical security / freedom from violence to the list of component objectives/criteria within 'human development', and as part of the bringing down to earth of the HD concept-back to substantive specified priority aspects of human life-from the abstracted capability heights of attainable valued opportunities. That physical security was from the mid 1990s incorporated into the definition of HD (see e.g. UNDP, 1996, p.56) contributed to the confusion that many feel in distinguishing between HS and HD. So some commentators seek to limit the meaning of HS to physical security alone, as we see shortly.

A third type of answer takes up a related but distinct aspect: it presents 'human security' as concerning the security of persons as opposed to the security of states. Typically even if not necessarily, it connects to the idea that state security will be precarious and expensive - and empty — unless based on and consistent with the security of individuals. A similar idea underlies John W. Burton's basic needs approach in peace studies (Burton, 1990; Mitchell, 2001).

We indeed require different security categories for persons and States. Variability for a person occurs over a time period; variability for a society has two dimensions: across persons and over time. Acharya (2001) addresses the issue in a table given here as Figure 1. The horizontal axis concerns how broad a range of objectives is covered by a concept; the vertical axis concerns 'security for whom?'. 'National security' centrally concerns physical security of a State. In contrast, Haq and UNDP's notion of 'human security' looks at all major aspects of security, and at how these impinge on the lives of individual persons, not at the level of a State. 
FIGURE 1: FOUR IMAGES OF SECURITY (adapted from Acharya, 2001, p. 14)

\begin{tabular}{l|ccc}
\hline & \multicolumn{3}{|c}{ ATTENTION TO WHAT TYPE OF THREAT } \\
\hline & & PHYSICAL VIOLENCE & PHYSICAL VIOLENCE \\
& & & $\&$ NON-MILITARY SECURITY \\
WHAT TYPE OF UNIT & INDIVIDUAL & 'Personal Security' & [UNDP's] 'Human Security' \\
& STATE & 'National Security' & 'Comprehensive Security' \\
\hline
\end{tabular}

Intermediate between those two, 'comprehensive security' was a state-focused concept, developed in Japan in the 1970s and 80s, that covered economic as well as military security. 'Personal security' corresponds to the Canadian/Norwegian government definition of 'human security': physical security of individuals. It reacts against both the UNDP notion of HS, felt to be too broad, and the traditional notion of national security, felt to be increasingly misleading or insufficient in an era when most violent conflict is intra-national and overwhelmingly most casualties are civilian.

So while the second answer ('freedom from fear as well as freedom from want') does not reduce human security to physical security alone, some variants of the third answer (security of persons) do so. The usage espoused by the Canadian government and Like Minded Countries group, that human security means the physical security of individuals, excludes freedom from want. Some even limit it to the physical security of persons (presumably non-military) during conflicts.

A fourth answer pays broader attention to the adjective 'human' than does any of the three previous ones. It considers what are the requirements of being 'human', in addition to sheer existence. These can go beyond freedoms from fear and from want. We might add freedom from humiliation and indignity. Mary Robinson, the former UN Commissioner for Human Rights, highlights also freedom from despair (Robinson, 2003). In contrast to the 'freedoms to' in the capability approach, which concern real potentials (freedoms to act and to attain) but not definite attainments, these 'freedoms from' concern definite absences not just potential absences. Some HS lists also include freedoms-to, such as the freedom of future generations to inherit a healthy natural environment.

For Sabina Alkire, who was senior researcher to the Commission on Human Security. 'the objective of human security is to safeguard the vital core of all human lives 
from critical pervasive threats, without impeding long-term human fulfilment. ... The term "vital core" is not meant to be precise; it suggests a minimal or basic or fundamental set of functions related to survival, livelihood and dignity' (Alkire, 2003, p. 24). This version of the fourth conception was largely adopted by the Commission, which defined human security as: "to protect the vital core of all human lives in ways that enhance human freedoms and human fulfilment' (Commission on Human Security, 2003, p.4). The approach draws from Hampson et al. (2002) and in specifics slightly augments Haq: 'Human security is not a concern with weapons - it is a concern with human life and dignity' (Human Development Report 1994, p.22). ${ }^{1}$

Human security so conceived concerns the securing of humanity, humankind; which must be ensured before 'cultivating humanity', if cultivation refers to fuller flourishing. For Alkire: in contrast to HD, 'The goal of human security is not expansion of all capabilities in an open-ended fashion, but rather the provision of vital capabilities to all persons equally' (Alkire, 2003, p. 36). ${ }^{2}$

In sum, we see several different types of answer regarding the purpose of the HS concept:

a) to complement the HD concept by a concern with the stability of whatever goods are highlighted within HD;

b) to broaden the scope of the HD concept, by including the physical security of persons; this answer is perhaps obsolete since the HD concept has made the addition;

c) to broaden the scope of the security studies concept of security, beyond state and military security; and/or to change the focus, to a concern with the (physical) security of persons;

d) to narrow down scope as compared to the HD concept, by concentrating on the basics (types and levels of goods required) for securing humanity.

Seen from the side of (military) security studies and policy, the Ogata-Sen HS concept can represent an extension from freedom from fear to include at least also freedom from want: because both are important and because of the expectation that the former will never be attained if the latter is not. Seen from the side of HD, it represents an extension 
from freedom from want to include (or highlight) also freedom from fear; but characteristically with a narrowing to concentrate on the highest priorities. ${ }^{3}$

The table in Figure 2 indicates how these various interpretations of human security can be compared with a base case which is not a concept of human security: case 0, a 'pure' capability approach definition of human development as expansion of valued capabilities. Darker shaded cells show diverse current concepts of human security, plus cells 2 and 11 which might also be propounded as interpretations of HS. Cell 3 is a borderline case; it is the current conception of human development, which includes physical security of persons. The columns concern how wide a range of objectives is included in the concept. Columns I and II have very broad ranges, from Human Development discourse; column IV a much narrower range, from security studies; and in between them column III, including the Ogata-Sen definition, has a less narrow scope than IV but less broad than I and II.

FIGURE 2: ALTERNATIVE DEFINITIONS OF HUMAN SECURITY (see shaded cells)

\begin{tabular}{|c|c|c|c|c|}
\hline & $\begin{array}{c}\text { I } \\
\text { HD AS [VALUED] } \\
\text { CAPABILITIES } \\
\text { EXPANSION } \\
\text { (e.g. HDR 1990) }\end{array}$ & $\begin{array}{c}\text { II } \\
\text { HD IN TERMS OF } \\
\text { UNDP'S LONGER } \\
\text { LIST OF GOODS } \\
\text { (e.g. HDR 1996) }\end{array}$ & $\begin{array}{c}\text { III } \\
\text { BASIC NEEDS } \\
\text { ONLY } \\
\text { (in terms of types } \\
\text { and level) }\end{array}$ & $\begin{array}{c}\text { IV } \\
\text { PERSONAL } \\
\text { PHYSICAL } \\
\text { SECURITY ONLY } \\
\text { (\& civil rights) }\end{array}$ \\
\hline $\begin{array}{c}\text { IN TERMS OF } \\
\text { LEVEL (snapshot } \\
\text { or trend) }\end{array}$ & $\begin{array}{l}0 \text { - Sen's Capability } \\
\text { Approach in } \\
\text { pure/minimal form }\end{array}$ & $\begin{array}{c}3 \text { - HDRs' focus } \\
\text { (includes physical } \\
\text { security) }\end{array}$ & $6-$ C. Thomas & $\begin{array}{c}\text { 9- Canadian \& } \\
\text { Norwegian govt. } \\
\text { definitions of HS }\end{array}$ \\
\hline $\begin{array}{c}\text { IN TERMS OF } \\
\text { STABILITY }^{4}\end{array}$ & 1 & 4 & 7 & 10 \\
\hline $\begin{array}{c}\text { IN TERMS OF } \\
\text { BOTH LEVEL } \\
\text { AND STABILITY }\end{array}$ & 2 & $\begin{array}{l}\text { 5- Haq's maximal } \\
\text { definition of HS; } \\
\text { Japan's definition }\end{array}$ & $\begin{array}{c}\text {-Alkire's \& } \\
\text { Ogata-Sen's } \\
\text { definition }\end{array}$ & 11 \\
\hline
\end{tabular}

Definitions of human security in terms of stability of achievement of valued or priority goods, as in the middle row, do not compete or overlap with definitions of human development; they are orthogonal to it, another dimension. They have some similarity of feel to column III, where human security is defined in terms of fulfilment of priority 
needs. Successful fulfilment of basic needs, 'the vital core', suggests their assured stable fulfilment. However these are again two distinct dimensions. One can have a stable but low level of fulfilment of priority needs or a fluctuating but on average high level of fulfilment over time; and across a population one can have high average fulfilment but considerable variation between people at a given time and over time. Fulfilment of basic needs is the main component in such a definition; the attention to stability is a refinement around that theme.

Given the relevance of both dimensions_-priority needs and stable fulfilmentand the advantages that we will see of a conception that is neither very broad nor very narrow, cell 8 presents an attractive concept of human security. I take it to be what Human Security Now proposes (see Owen, 2004 for a similar conclusion). It adopts a via media between maximalist and minimalist interpretations of scope of objectives: more focused and manageable than the maximalist interpretation; not arbitrarily restricted like the minimalist interpretation, which fails to see that much more premature death and human wounding arise from poverty than from physical violence; but restricted instead according to a criterion of reasoned prioritization within a political community. It brings an explicit concern for all human lives.

Haq may have used all of these types of answer at different points. Certainly he sometimes implied that HS subsumes HD by adding more concerns (see cases $3,4,5$ ). He discussed global public goods issues under the HS heading. As a policy entrepreneur he sought to influence and mobilize not just a single constituency, but to bring together various groups. Each of the answers might be seen as a facet of a more complex whole. Trying to precisely specify that inevitably somewhat general whole may not always be the best way of influencing and mobilizing, compared to presenting the vivid facets.

Let us take stock. As summarized in Figure 1, the UNDP concept of human security involves a focus on individuals and on a broader range of aspects of their security than only physical safety and survival. As summarized in Figure 2, in specifying that range of aspects so as to make the concept sharper and more distinctive, the Human Security Now formulation in terms of, in effect, basic needs plus stability is persuasive. Hubert (2004) suggests however that given the development-human security nexus- the interconnections of what have been conventionally separated spheres-it makes little 
difference in the end whether the concept adopted of human security is broad or narrow: for human security will not be achieved without development, nor vice versa.

A discourse is more than a concept. Through the concept, attention is directed to a widened, yet prioritized, set of key aspects, and to stability. The discourse involves further the normative claims that what matters is the content of individuals' lives, including a reasonable degree of stability; and the predictive/explanatory hypotheses that a broad set of aspects not conventionally connected in theory are often importantly connected in reality: including that the economic, social, cultural, medical, political and military are not separate systems; and that neither national nor personal security will be secured by military means alone. Let us look next then at the overall discourse, and at whether it represents anything new.

\section{The Good Old Wine Of Basic Human Needs ...?}

\section{The Human Security and Basic Human Needs conceptions compared}

If the essential feature of the human security concept is to prioritize within the human development realm, is this not simply the good old wine of basic human needs, rebottled and relabelled for a new generation? Why add a new label for an old concept? Why not keep that label for a distinctive use, such as physical security of persons? When one reads definitions like 'Human security may be defined as the preservation and protection of the life and dignity of individual human beings' (Takasu, cited in Harvard, 2002), or about 'The task of carving out a certain subset of material and political needs around which to form a consensus for concerted action' (Alkire, 2003, p. 28) anyone familiar with the Basic Human Needs (BHN) school of thought from the 1970s and later has powerful feelings déjà-vu.

The label and the concept-bottle are indeed new-Alkire appeals to the fact that 'the term "vital core" is not yet claimed by any approach' (Alkire, 2003, p. 25) —and later we will look at what significance this may have. But what of the wine? The answer, I think, is that in most respects HS is the same as BHN, but not in all. We have just seen that there is an HS discourse, not only an HS concept. That discourse includes also a style of analytical integration or open systems analysis, and - at least in some major variants- 
a normative insistence on the inviolability of basic human needs, their status as human rights. Neither of these features was always or necessarily part of the BHN work. Both features do appear in some of the leading BHN statements, for example by Johan Galtung (e.g. Galtung, 1980, 1994). Galtung was also one of the founders of peace research in the 1950s, in which field he continues as a central figure after a lifetime of work, and has further been one of the most penetrating thinkers on human rights (Galtung, 1994). Few are better qualified to assess whether the HS concept and discourse contain anything new. He addresses the question in a recent paper.

'Concepts come and go.... "Human security" is in, "humanitarian intervention" is on its way out. .... Cruel, but such is the life cycle of concepts.' (Galtung, 2004, p. 1). Paradigms become exhausted, or boring, or an obstacle to the advance of new aspirants, who may present their own views as something importantly different and superior, through reductionist description of previous work. '... in the 1970s a highly successful paradigm under the heading of basic human needs (BHN) made its round through the members of the UN family. It came with basic human rights; not only the Universal Declaration of 10 December 1948 but also the Social, Economic and Cultural Covenant of 16 December $1966 \ldots$... [and attempted] to establish the sine qua non, the nonnegotiable conditions, not only for a being, for life, but for a human being. ... The basic needs paradigm has not been exhausted, neither intellectually, nor politically.' (Galtung, 2004, p. 2). 'Very much of what has been mentioned [in Human Security Now] is in the basic human needs tradition .... [But] No doubt "human security" is...developing that approach further', extending it (Galtung, 2004, p.7).

Let us look first at the continuities behind the surface divergences, and then at possible substantial differences. We concentrate on Alkire's formulation which underlies Human Security Now. Alkire recurrently talks of 'what people valued or needed at a very basic level' (Alkire, 2003, p.24), 'a minimal or basic or fundamental set of functions' (p.24), 'basic capabilities' (p.36), and so on. She suggests that the HS concept is distinct by being stated in the language of freedoms: of capability not functioning (Alkire, 2003, p. 27). Various formulations of basic needs theory have however involved capability (e.g. Gasper, 1996), including probably the leading contemporary statement (Doyal and Gough, 1991), as we will see shortly. Such formulations are also in the style that Alkire 
specifies for Human Security Now's umbrella definition: a generalized statement that can subsume the more specific formulations crafted for particular institutional and cultural contexts. Specification of what is vital/basic is partly a matter for each political community and will depend partly on environmental conditions, but is sure to include some standard shared requirements.

Revealingly, in a lengthy section that compares Human Security with other policy frameworks - state security, Human Development, and human rights-Alkire does not discuss Basic Human Needs, except briefly as a precursor of HD (Alkire, 2003, p.35). She tends to conflate BHN work with the Basic Material Needs approach of some 1950s1980s planning agencies and development banks, which reduced human needs to only material needs or considered that those have exclusive priority. ${ }^{7}$ This conflation is commonly linked to equation of basic needs work to a simplified representation of the needs theory of Abraham Maslow. Maslow posited a prepotent hierarchy of needs, with physiological needs felt the most intensely until they are fulfilled, followed by safety needs, and so on. But even in the earliest statement of his theory (Maslow, 1943) he expected that needs were active concurrently, although the balance between them would vary according to the posited hierarchy; and his late work acknowledged the central importance of non-material needs at all stages.

A more sustainable contrast between much HS work and at least some needs approaches concerns aggregation. Much needs-based planning concerned itself with a broader range of goods than those measured by money but shared the readiness of money-metric approaches to aggregate across people. This brings the risk, in practice, of some people being sacrificed 'for the greater good': even that some people's basic needs will be sacrificed for the fulfilment of less pressing needs or wants of a large number of other people. Much HS work now adopts a human rights stance: the basic requirements of no individual are to be sacrificed.

\section{Human Security as a generalized, rights-conscious child of the BHN approach}

Not all needs approaches have adopted the concept of human rights. But human rights - rights that apply for every person because she or he is a human - can be seen as rights to the fulfilment of, or ability to fulfil, basic human needs. These needs provide the 
grounding for human rights. 'Behind human rights are freedoms and needs so fundamental that their denial puts human dignity itself at risk' (Goldewijk and Fortman, 1999, p. 117). Basic human needs are whatever people require to be able to achieve a level of functioning that satisfies a given ethical conception of the acceptable minimum; such conceptions include, for example, human dignity, or the avoidance of serious harm. ${ }^{8}$ The needs implied by these conceptions typically include, in particular, basic levels of physical and mental health.

Galtung has refined this picture. Not all needs correspond to rights, and not all rights correspond to needs. But a central set of human rights rest on basic needs. $\mathrm{He}$ warns that the traditional human rights approach connects better to survival needs and freedom needs, "needs that are more clearly threatened by deliberate acts of "evil" actors', and for which we can more readily state norms in the form of rights that imply duties by specific actors. In contrast, identity needs and some other needs 'are more often impeded by “wrong” structures' (Galtung, 1994, p. 69). Here a post-traditional approach is required; 'needs rather than rights direct us to look for causal factors rather than evil actors' (Galtung, 1994, p. 55).

Human rights can in turn be seen as essential partner to the discourse of basic needs. They provide an insistence on the value of each person, and a strong language of prioritization. These features focus one's attention and energies: 'in adverse environments, the primary meaning of human rights is to make people aware of what is basically wrong' (Goldewijk and Fortman, 1999, p. 117). And when widely acknowledged as norms or legally recognized as instruments, rights form a major set of tools in the political struggles to claim fulfilment of needs. Sacrifice of the basic needs, the health and prospects, of millions of people in very poor countries in order to service debts to far richer groups had become unsurprising and normal in the 1980s and 90s. The 'Jubilee 2000' campaigners for debt relief achieved new impact by showing how such cuts contravened the Universal Declaration of Human Rights (UDHR) endorsed by nearly all governments, including the debt collectors (Hanlon, 2000). The UDHR prioritizes access to education and health care. In welfare-states, when a family goes bankrupt no child is expected to lose access to basic education and health care in order for debts to first be repaid. Similar principles should apply for people everywhere. 
A connection between conceptions of needs and human rights has long been proposed, but not absorbed as a standard formulation. One still encounters social science dictionaries in which adjacent entries on human needs and human rights contain no reference to each other's language. The two ideas have been primarily located in different disciplines and fora: rights more in the worlds of law, social movements and 'humanitarian intervention', needs more within social and economic policy and planning and 'humanitarian relief'. Added to this have been confusions around needs discourse, attacks on it by many libertarians and free-market advocates, and antagonism by some socialists and economists to rights formulations. In the past twenty years these obstacles have diminished and the fundamental connection of the two bodies of thought has become evident, in work by, for example, Galtung, Gewirth, Sen and Waldron.

Rights are 'justified claims to the protection of persons' important interests' says Gewirth (1995). Such 'claim-rights' have this structure: Person/subject A has a right to entity $\mathrm{X}$ against duty-bearer B by virtue of ground $\mathrm{Y} .{ }^{9}$ For 'human rights' the proposed ground is that the entities $X$ are requisites for being human in a morally acceptable sense. According to Gewirth they are 'the goods that are necessary for human action or for having general chances of success in achieving one's purposes by action'. Shue (1980) refers similarly to 'basic rights', those which are necessary to enjoy all other rights. In normative needs discourse they are basic needs.

The concept of need arises in three importantly different modes. First, 'needs' in explanatory theory are underlying motives or drives. Second, instrumental needs are the requisites $(\mathrm{X})$ for attaining a given goal $\mathrm{G}$. Third, needs in normative theory are justified priorities based on a 'relational formula': person A needs entity $\mathrm{X}$ (or an equivalent 'satisfier') in order (reason Y) to do or attain goal G which is a justified high priority ín the relevant political community. Whether, in particular cases, entity $\mathrm{X}$ brings fulfilment of a drive or motive is a matter for positive investigation. Whether entity $\mathrm{X}$ really is required for achieving goal $\mathrm{G}$ is an instrumental issue for examination. Whether $\mathrm{G}$ really is or should be a high priority is a matter for normative debate and legitimate political process.

Normative needs discourse thus has the same structure as claim-rights discourse. This can be obscured by failure to distinguish the three needs modes and also the various 
levels in the chains of instrumental and normative relations (Gasper, 2004). Sen's categories of capability and functioning help us to discuss levels more clearly. Just as needs concepts exist at several levels, so do rights concepts.

Figure 3 uses the structure of the prominent normative needs theory by Doyal and Gough in order to compare ethics of capabilities, needs, and human rights. As argued by Penz (1991), the three types of ethic are closely connected and complementary not competitive. Human security discourse builds on this potential, bringing together what was previously artificially separated.

FIGURE 3: COMPARISON OF HUMAN SECURITY, HUMAN NEED, AND HUMAN RIGHTS CONCEPTS

\begin{tabular}{|c|c|c|c|c|c|}
\hline & Basic Criterion & $\begin{array}{c}\text { Requirements in } \\
\text { order to fulfil the } \\
\text { basic criterion } \\
\text { (Needs level 1) }\end{array}$ & $\begin{array}{c}\text { Required } \\
\text { satisfier } \\
\text { characteristics } \\
\text { (Needs level 2) }\end{array}$ & $\begin{array}{c}\text { Specific required } \\
\text { satisfiers } \\
\\
\text { (Needs level 3) }\end{array}$ & $\begin{array}{c}\text { Required } \\
\text { preconditions } \\
\text { (Needs level 4) }\end{array}$ \\
\hline $\begin{array}{c}\text { HS: } \\
\text { prioritization in } \\
\text { the categories of } \\
\text { the capability } \\
\text { approach and } \\
\text { UNDP's 'Human } \\
\text { Development' }\end{array}$ & $\begin{array}{c}\text { Priority } \\
\text { functionings: } \\
\text { 'vital core' }\end{array}$ & $\begin{array}{l}\text { Capabilities that } \\
\text { are required to } \\
\text { achieve the } \\
\text { priority } \\
\text { functionings: } \\
\text { 'basic } \\
\text { capabilities' }\end{array}$ & $\begin{array}{l}\text { 'Characteristics' } \\
\text { of goods that are } \\
\text { required to } \\
\text { achieve those } \\
\text { capabilities }\end{array}$ & $\begin{array}{l}\text { The goods / } \\
\text { 'commodities' } \\
\text { that are required } \\
\text { to provide those } \\
\text { characteristics }\end{array}$ & $\begin{array}{l}\text { The societal } \\
\text { conditions that } \\
\text { are required to } \\
\text { sustain the supply } \\
\text { of those goods }\end{array}$ \\
\hline $\begin{array}{c}\text { Doyal \& } \\
\text { Gough's main } \\
\text { formulation of } \\
\text { human needs as } \\
\text { normative } \\
\text { priorities }\end{array}$ & $\begin{array}{l}\text { Avoidance of } \\
\text { serious harm }\end{array}$ & $\begin{array}{l}\text { Health, physical } \\
\text { and mental; } \\
\text { autonomy of } \\
\text { agency }\end{array}$ & $\begin{array}{c}\text { Nourishment; } \\
\text { housing; } \\
\text { secure } \\
\text {-childhood \& } \\
\text {-environment; } \\
\text { work; health care, } \\
\text { education, etc. }\end{array}$ & $\begin{array}{l}\text { The satisfiers } \\
\text { required } \\
\text { vary according to } \\
\text { geographical, } \\
\text { socio-economic } \\
\text { and cultural } \\
\text { setting }\end{array}$ & $\begin{array}{l}\text { Conditions } \\
\text { concerning } \\
\text { production, } \\
\text { reproduction, } \\
\text { cultural } \\
\text { transmission, and } \\
\text { political authority }\end{array}$ \\
\hline $\begin{array}{c}\text { From Goldewijk } \\
\text { \& Fortman's } \\
\text { formulation of } \\
\text { human rights }\end{array}$ & $\begin{array}{l}\text { Dignity / non- } \\
\text { humiliation, } \\
\text { Self-respect }\end{array}$ & $\begin{array}{l}\text { Equality and } \\
\text { freedom; or, } \\
\text { equality and } \\
\text { agency }\end{array}$ & $\begin{array}{l}\text { The satisfier } \\
\text { characteristics } \\
\text { required for } \\
\text { equality and } \\
\text { freedom/agcncy }\end{array}$ & $\begin{array}{l}\text { Specific satisfiers } \\
\text { that provide the } \\
\text { required } \\
\text { characteristics; } \\
\text { vary by setting }\end{array}$ & \\
\hline
\end{tabular}


Human rights theory links to needs theory: human rights are legitimated claims/ entitlements 'grounded in basic needs' (Goldewijk and Fortman, 1999, p. 120). Normative needs theory links readily to HD's capability approach: the capability of autonomous agency stands together with health as the central moral priority, the criterion for need, in Doyal and Gough's theory. Prioritization in the capabilities/HD language now begins to often use the label 'human security'. Nussbaum (2000) does not, but proposes similarly that many human rights are best seen as rights to basic needs, seen in turn as basic capabilities to function (Gasper, 2005). Using the capabilities language and rights language together highlights respect for persons as choosers. For Leaning (2004), human security means ability to secure basic material and psycho-social needs. Thus, Galtung can, broadly speaking, conclude that human security is the fulfilment of basic human rights which are in turn the fulfilment of basic human needs. In his model these are survival, wellness, freedom and identity (e.g. Galtung, 2003, p.7). Since poverty is the main killer and wounder, he emphasises that human security centrally concerns the assurance of subsistence.

In sum, 'human security does bridge a number of previous concepts' (Alkire, 2003, p. 25). The human security concept of Human Security Now tries to combine HD discourse's broad focus and stress on reasoned freedoms, BHN discourse's stress on prioritization, and HR discourse's unwillingness to sacrifice anyone. This brings potential advantages and potential pitfalls.

One potential advantage is that human rights, as in Gewirth's formulation, may not only generate specific claims for and by the needy, as in the work on basic needs and human development, but also specific duties and thus accountability (St. Clair, 2004b). Alkire puts this emphatically: 'the human rights approach holds the notion of obligation and duty centrally'; and the human rights vocabulary even brings an 'automatic sense of moral obligation' (Alkire, 2003, pp. 26, 39). However, an Achilles heel of human rights work in the past has been that even when people agree that someone should ensure $\mathrm{X}$ they frequently disagree on whom that someone is. The rights language has often become detached from accountable duties (O'Neill, 1996). This is now the focus of intense attention. 
A second potential advantage is that the human security work accepts more fully than the human rights tradition the necessity often for prioritisation. Human rights concepts are often too absolutist (Commission on Human Security, 2003, p. 28). Alkire hopes that human security discourse can take over strengths of the human rights language while avoiding some of the old disputes and connotations (Alkire, 2003, p. 39). Charlotte Bunch warns that if HS discourse simply displaces rights discourse, it could be led back to a stress on needs alone not on needs as rights, precisely in order to weaken the obligations of the privileged (Bunch, 2004).

The human security discourse is a radical, rather optimistic package. Trying to bridge concepts that are in tension, like prioritization and non-exclusion, imposes high demands for intellectual and practical creativity and power. In the following section we look at the effectiveness of the package as a whole, with attention to both the contents and the packaging.

\section{... In A Well-Labelled and Attractive New Bottle? The Possible Boundary Roles of 'Human Security' Discourse}

HS discourse remains widely seen as vague, a ragbag of concepts. Sen's fondness for integration via freedoms-formulations confuses and alienates some audiences while it appeals to others. As with his freedoms language, adoption of the 'security' label is perceived by some as drinking from a poisoned chalice rather than as its purification; even as acceptance now of a fearful American agenda marked by fantasies of invulnerability. The approach is attacked as too broad to be operational or have policy value; as too individualistic, even too Christian (despite the backgrounds of Haq, Ogata, Sen, et al.!); as old wine in an unhelpful new bottle.

To view some of these objections in a more profound way than by proceeding through them as isolated items on a list, I will employ a framework from the sociology of policy-relevant scientific research and policy debate. Asuncion St. Clair (2004a, 2004b) suggests that we view 'human security' as an intellectual 'boundary object': a conceptualization that attempts to bridge between different intellectual and professional worlds, notably between the worlds of science and policy. In assessing an intellectual 
construct we need to consider its function and its relation to complementary constructs, rather than view it in isolation and beg the questions of its function and context.

\section{Human Security as a 'boundary object'}

The Human Security approach-namely the HS concept, in particular the version in Human Security Now, plus the associated normative and theoretical organizing principles in the HS discourse - seems to have 'all the right bells and whistles' suggests Bernstein (2004, p.3). What in fact are 'the right bells and whistles' for an intellectual construct in the world of international development policy?

Work in the sociology of science and science-based policy has examined the interfaces between different intellectual communities: between scientists and funders, notably including politicians; between different scientific and technical disciplines, between international and national bodies, and so on. Boundaries can become managed by special 'boundary organizations' which have the task of somehow marrying the different concerns of the different stakeholders. 'Boundary objects' are practices, ideas or sets of ideas that are employed for the inter-community interchange (Star and Griesemer, 1989). Boundary objects must be malleable enough to be used by diverse parties, while robust enough to keep sufficient shared meaning across this range of users. A boundary organization should have accountability mechanisms: to regulate the trading in ambiguous meanings; to control the influence of politics on approval of knowledge claims; and to regulate the influence of knowledge claims on politics in order to prevent technocratic rule by values that are undeclared and not democratically considered.

Boundary work at the borders of theory and policy in national and international development circles is particularly complex. Multi-national, multi-disciplinary, multiagency contexts bring special demands for participation, trust and equity, including procedural equity. International development agencies have typically not adequately theorized the boundary work in which they engage, because of rosy myths such as that economic growth will bring all good things and that everyone agrees on the value content of 'development' (St. Clair, 2004b).

St. Clair discusses which factors make for successful intellectual 'boundary objects' that contribute to ethically progressive interventions in these contexts. She 
argues that propounding ethical claims alone is not very effective. We need rather to embody conscious ethical meanings into boundary objects which frame and regulate boundary work. Boundary objects with embodied ethical concerns survive better the rough-and-tumble of policy debate where power pressures, disciplinary habits and other forces enter. Ethical concerns should be embedded in a policy/planning approach rather than left as disembodied words, detached from action and power.

The World Bank has operated as a potent boundary organization that wields considerable authority in the worlds of both science and policy. Its scientific views are accepted by many as non-political and its policy views as scientific. While ethical principles are embedded in the bulk of its work they are not mainly the ones that it declares, concludes St. Clair. This value-concealment derives from the Bank's adherence to the cognitive values of mainstream economics, which suppress discussion of ethical values and believe that analysis is not partly guided by value-laden choices. The Bank presents its analyses as established truth; it has not seen or presented, for example, the value-elements in its conceptualization of poverty. Its work has been dominated in practice by the following cognitive preferences: for atomism, individualism, quantification, and the simplified and clearcut or emphatic; and often by the ethical values that are implied in interpretations of consumer sovereignty and (economic) efficiency which exclude evaluation of preferences and in practice balance interests in proportion to persons' purchasing power. The concept of efficiency is a key boundary object whereby the shuffle between declared and actually predominant values occurs. A narrow market-economic interpretation of efficiency is treated as efficiency as such, despite its exclusion of many categories of values and its weighting commonly even of monetized objective-fulfilment in proportion to people's purchasing power (Gasper, 2004). This interpretation matches the financial interests of the wealthy; and simple clear numerical conclusions fit the preferences of many policy makers. The World Bank's role as a boundary organization has thus, argues St. Clair, often been less to manage learning at its complex intellectual-political crossroads and more to defuse ideas from outside the economics mainstream that has suited the major powers who dominate the Bank. It is clear who 'wins' disputes in the Bank: not Stiglitz, Kanbur or Easterly. Its commitment to human development has remained secondary to economic growth, and in practice has 
often reduced to attention to education and health. Thus in the Bank's boundary work its publicly declared ethical commitments typically become coopted and distorted. ILO's 1970s Basic Needs Approach (e.g. ILO, 1976) was taken over in this way by the far richer organization. The space for debate was undermined, with a stifling of major value debates and even of some empirical debates. The coopted version of BNA subsequently failed as a boundary object, concludes St. Clair.

From his experience of leading the work on basic needs in the Bank in the 1970s, Haq knew the countercurrents from wealth-based politics and the conventional economics that it funds. He drew as lessons: the importance of vivid concepts to mobilize support, and of organizational autonomy in order to elaborate, defend and disseminate alternative ideas. When he joined UNDP at the end of the 1980s, he insisted on a new division with editorial autonomy to run the $H D R$ series and to bring the enlivening notion of Human Development to wide audiences. Thanks to Haq, UNDP at last achieved important independent intellectual influence despite its pitifully small levels of research funding compared to those in the World Bank or IMF. Indeed it came to set the agenda.

UNDP's policy discourses have presented and preserved, not disguised or degraded, powerful moral concepts, argues St. Clair (2004a, 2004b). Its boundary objects have directed attention to people's lives, local situations and learning paths. The HD language centres on attainable options, thus retaining a strong connection to economists; but it is not easily coopted and reduced for it is so explicit on its values and on including all of life beyond only the monetized and monetizable. Its impact on policy has been less than on prose, yet positive and unexpected.

This sociology-of-science perspective helps in responding to some of the objections made to HD's partner, the HS discourse. Is the boundary object 'human security' a vague, incoherent ragbag of different concepts? 'Human security' has arisen at the interface of several streams, but the concept can be adequately clarified, as in Human Security Now. The formulation there certainly leaves still considerable space. Perceptions of what is the 'vital core' will differ; and perhaps some of the rich will defend their every penny as supposedly vital for their well-being, but the debates are now brought into the open not concealed under economics conventions. Alkire argues that the generality of the HS concept is a virtue. It appropriately allows HS to encompass many variants and to 
reflect different priorities in different times and places, including according to "the comparative advantage of the implementing institution' (Alkire, 2003, p.10), while giving still a unified prioritizing focus. A boundary object in global discourse must provide this space for local interpretation and application. But is it so broad as to be non-operational and unmanageable for policy? The rapid translation since the mid 1990s of the HS agenda, from motivating paradigm to operations-oriented frameworks, not least in what have become Millennium Development Goals programmes, shows that this is not true. ${ }^{10}$ A good boundary object in development policy must be more than a general ideal like equity or freedom: it should span between ideals, concrete life situations and actions. This is the heart of politics. 'Human security' essays just that.

So the HS framework is proposed as a more effective 'boundary object', to take over the baton from 'Basic Human Needs'. Let us try to specify more exactly its possible functional contributions, and note finally various doubts and misgivings.

\section{Roles: Integration, Prioritization, Motivation, Operationalization}

The clarified HS discourse of Human Security Now makes several significant contributions. Nearly all the roles are understandable as 'boundary work'. First, like its HD sibling, it insists on analytical integration: it directs us to examine major connections, across the disciplinary and national boundaries that continued as convenient dividers for the predominant powers in the post-1945 order. The HS and HD framework traces connections, for example from postcolonial structures and world economic power balances to debt crises, to economic regimes imposed in poor countries, to social conflicts, to armed conflict, to economic collapse, to banditry as a profession; and from economic, social and military crises to health pandemics, the global drugs trade, domestic conflicts and changing gender roles. HS work's special attention to causes, costs and other effects of violent conflict is an essential contribution to realistic understanding.

Second, this broad field of attention, with different aspects treated in an integrative rather than merely additive fashion, helps to involve and interconnect more organizational worlds-Uvin mentions the four traditionally separated fields of 'humanitarianism, development, human rights, and conflict resolution' (Uvin, 2004, p. 353) - including the highly-funded worlds of 'national security'. It can connect a wider 
range of organizational fora, which it helps to mobilize for responses to the crises of the post-1945 order, especially post-1989.

Third, in St. Clair's terms, the human security discourse provides a boundary object that is imbued with ethical concerns for equity. In a world where equity in participation remains remote, it is particularly important to embed equity concerns in the conceptualization of policy issues.

These first three attractions are those of the HD approach too. HS discourse adds a particular slant but without strong distinctiveness. The features are shared to some degree across all the conceptions of HS in Figure 2. The next three features are more distinctive to HS discourse and especially to the formulation found in Human Security Now.

Fourth, compared to its HD sibling, HS work prioritizes much more, by its focus on basic needs. It thus has more immediate policy relevance. This is why Haq so quickly added a concept of human security to partner yet overlap the still embryonic human development concept. Within the vast stage of human development a priority zone was urgently required. The term 'security' conveys that. ${ }^{11}$ We will come back to its possible dangers.

Fifth, the HS discourse in particular helps to motivate action, by its foci on individual human beings, their vulnerability, and, in the case of Human Security Now, on their basic needs. The HD approach broadened and re-cast the attention to the meaning and ends of development, but provided no clear guarantee for individuals. Many could still be sacrificed in the course of bringing the broad range of good things to the majority, by governments who warmly adopted the language of human development. And it presumed rather than itself helped to build a motivational basis to answer: why should one adopt this broader range of objectives and why one should bother about psychologically and/or geographically distant others? HS discourse looks more vividly at the suffering and vulnerability of individuals, not only at statistics on disease and disability. Human Security Now in particular looks at people as agents, across the "vital core' of their lives, not only at isolated dimensions of nutrition, longevity or violence. The languages of fear and of central aspirations convey more, about people who strive 
and feel. Thus, vitally for a policy framework, the exercise of integration extends to include the emotions too (Gasper and Truong, 2004).

Sixth, the discourse connects to an accountability structure: via the UN system (as seen in the monitoring of humanitarian crises and of progress towards the Millennium Development Goals) and potentially via the systems of human rights law (Bunch, 2004). Operating within these institutional frameworks-global, national and local Human Development Reports, other UN reports, MDG reports, and international conventions that are increasingly referred to, or incorporated into, national law-human sympathy has tools to sustainably work with and through.

The 'security' label

'Human security' discourse motivates in part through connotations of the noun 'security'. The noun is a potent term in the international arena thanks to the UN Security Council, US National Security Council, and the like. The dominant body in the UN system is the Security Council, controlled by the five states victorious in World War Two. This body is supposed to maintain peace. Haq called for the addition of an 'Economic Security Council' (ESC). His $H D R$ work was the source of the analysis but physical and state security was the source of the language. It may seem odd that Haq did not call for a Human Security Council, since he constantly said it was to deal with human security. But the existing Security Council also affects at least part of human security. The ESC label too was unattainable; rich countries will not allow an ESC in the UN. Others now ask for a differently labeled Council. Even with another label, however, the agenda that Haq sketched for such a Council was threatening; for example, to commission coordinated analyses of major interlinked crises, notably the linkages from poverty to global insecurity and vice versa. He proposed that the ESC would dealpreemptively and preventively via development support measures — with all major intranational crises where there is no legitimate national authority. This seems inconsistent with the proposed label and implausible in power politics terms. He called too for unification of all UN and Bretton Woods agencies under the HD banner. Overall, his plan (Haq, 1999, p. 196) had no chance of short-run success and one guesses that he saw it 
instead as part of a longer term campaign. One day more of the Berlin Walls erected by World War Two's victors must come down.

The noun 'security' derives from a more fundamental concept, the adjective 'secure'. 'Secure' means 1. free from danger, damage, or 2. free from fear, care, etc., says the Collins English Dictionary. We can call these the objective and subjective variants of security. Collins goes on to specify 'security' as a. the state of being secure, b. assured freedom from poverty or want, or c. precautions taken to ensure against loss.

'Secure' figures also as a verb. To secure is: 3. to make or become free from danger, fear etc.; 4. to obtain or get possession of, or 5. to make or become certain, guarantee. We speak of securing basic rights and freedoms. The thrust of Human Security Now might be better conveyed through the verb than the noun, as in the phrase 'Securing Humanity'. Like Martha Nussbaum's book title Cultivating Humanity, the phrase contains a dual message: in this case, of making people free from fear and want and indignity, and of promoting humane attitudes.

Nevertheless, the noun 'security' itself packs important messages—safety, home, inclusion-especially when allied with the adjective 'human'. For messages about a shared future for a region or for the planet, the phrase 'Our common home' is more powerful than 'Our common future'. 'Homeland security' is the phrase chosen in America post-'9/11'. In this context, Galtung warns that Human Security Now:

legitimizes the word "security" by giving it the connotation "human". What then happens is beyond the pages of the report. We would expect the state system with its monopoly on the violent means of security to use this legitimation, justifying intervention inside other states in the name of "human security". (Galtung, 2004, p.7)

HS proponents claim that 'human security' discourse works not with irredeemably soiled conceptual goods but with unavoidable and indispensable motivating concerns. Mamphela Ramphele, World Bank vice-president, sees it as 'taking the sting out of this national security preoccupation', using and redirecting its energy (Ramphele, 2004, p.3). The HS framework can, via its analytical integration, clarify the prerequisites of national security ('no national security without human security'); and enlist such concerns towards forming an imagined (not imaginary) community beyond and in 
addition to the nation - so runs the optimistic implicit hypothesis. Is there enough potential for maturation? How far has American 'homeland security' the same emotional roots as super-hero books and Ronald Reagan's 'Star Wars': the search for a technical fix that will safeguard the chosen people against evil alien intruders? This is the opposite of any intellectual or sympathetic opening-up in considering one's relations with others. HS discourse does not however depend on Ramphele's stronger claim of extracting the sting, but rather on the claim to work with indispensable motivating concerns. We should remain wary of the potential sting.

Ramphele herself observes that total security is impossible and undesirable (Ramphele, 2004, p.4). It can induce inertia and alienation. Just like a being that is immortal, a being that is invulnerable is not human. This may be more than just a description of current human powers. Unlike say inability to fly, another limitation overcome by the super-hero, vulnerability is perhaps not a suppressible incidental feature of humanity. The feeling of invulnerability might make one inhuman, without sympathy; or at least, less prone to be open to others and less prone to sympathy. The Nietzschean superman may even actively cultivate such super-/in-humanity. It is the opposite of the HS discourse, which seeks to manage and moderate vulnerability. HS discourse involves being open to the vulnerabilities of others partly because one shares such vulnerabilities oneself.

A possible Achilles heel of the approach is that feelings of security are subjective. We say that $\mathrm{X}$ is a secure person and $\mathrm{Y}$ insecure, referring to their personality not their circumstances. Security, like well-being, has both subjective and objective aspects. It makes no sense to ignore either. Thus Leaning and Arie's definition of human security (in Harvard, 2002) concerns psychological security, presented as an important resource in dealing with the objective insecurity in a person or group's environment. Studies indicate that felt insecurity is often unrelated to objective insecurity, indeed sometimes it is inversely correlated. The danger arises that a human security agenda could be hijacked by the fears of the rich. Caroline Thomas (2004) concludes that the key test is whether the integrative analytical agenda of the HS discourse really will focus the attention of the powerful on the connections between freedom from fear and freedom from want, indignity, humiliation and despair. 


\section{Conclusion}

Part I of Mahbub ul Haq's Reflections on Human Development is titled 'Towards a New Development Paradigm'. It presented the innovative and inspirational intellectual journey of emergence and elaboration of the human development approach. Part II is titled 'Towards a New International Dialogue'. Its chapters, written on average somewhat later, present the harder, practical struggle of seeking to influence policy-making institutions: finding the language of human security to focus on priorities, looking for the peace dividend, redirecting development cooperation and international organizations. The human security discourse is a discourse for getting priority, and priorities, in national and international policy. The approach has been consolidated by the Ogata-Sen commission in Human Security Now. I have tried to characterise and assess it, with attention to the label 'human security', to the concept behind the label, and to the overall discourse and the tasks that it attempts in the painful worlds of international relations and development policy.

Human development discourse widens the range of concerns beyond economic growth; better put, it respecifies the range of concerns so that economic growth becomes seen as one potential means and not an end in itself, let alone the single or predominant end. The human security concept as clarified in Human Security Now adds two fundamental elements. A concern with the physical security of people is not novel, for that is present in HD. The additions are, first and most important, a focus on priorities within the widened range of concerns: broadly speaking, a focus on basic human needs. The second is a focus on stability, not only averages and trends.

The HS discourse includes, besides the concept, strong attention to the interconnections between conventionally separated spheres, which helps it to link diverse organizational worlds; and a motivating focus on human vulnerability and the human rights that flow for every human being from basic human needs. The 'human security' label for the concept and discourse well matches their contents and purpose, but carries risks: there are other contenders for the label, coming from national security studies, and possible distorting forces from the psychological insecurities of the rich. Nevertheless, 
the overall package of concept, label and discourse serves as a promising framework for the 'boundary work', intellectually, emotionally, ethically and politically, involved in connecting different disciplinary and organizational worlds, and embedding priority human concerns into analytical and policy agendas.

\section{REFERENCES}

Acharya, A. (2001) 'Human Security: East versus West?' Working Paper 17, Institute of Defence and Strategic Studies, Singapore.

Alkire, S. (2003) 'A Conceptual Framework for Human Security', CRISE Working Paper 2, Queen Elizabeth House, University of Oxford.

Bernstein, A. (2004) Respondent Remarks, seminar at the National Council for Research on Women, Washington, DC, March 11, www.ncrw.org/interest/bernstein remarks.htm

Bunch, C. (2004) 'A Feminist Human Rights Lens on Human Security', Peace Review, March 2004.

Burton, J.W. (1990) Conflict: Basic Human Needs, St. Martin's Press, New York.

Commission on Human Security (2003) Human Security Now, New York.

Doyal, L., and Gough, I. (1991) A Theory of Human Need, Macmillan, Basingstoke.

Galtung, J. (1980) 'The Basic Needs Approach', in K. Lederer (ed) Human Needs, Oelgeschlager, Gunn \& Hain, Cambridge MA.

Galtung, J. (1994) Human Rights in Another Key, Polity, Cambridge.

Galtung, J. (2003) 'Meeting Basic Needs: Peace and Development', for The Science of Well-Being, edited by N. Baylis et al. (2005) Oxford Univ. Press, Oxford.

Galtung, J. (2004) 'Human Needs, Humanitarian Intervention, Human Security and the War in Iraq', http://www.transnational.org/forum/meet/2004/Galtung_HumanNeeds.html

Gasper, D. (1996) 'Needs and Basic Needs - a clarification of foundational concepts for development ethics and policy', in Questioning Development, ed. G. Koehler et al., Metropolis: Marburg.

---- (2004) The Ethics of Development, Edinburgh Univ. Press, Edinburgh.

---- (2005) 'Human capabilities', in Encyclopaedia of International Relations and Global Politics, ed. M. Griffiths, Routledge, London.

----, and Truong, T-D. (2004) 'Deepening Development Ethics Through the Lens of Human Security: Care, Migration and Women's Lives', paper for CGIR conference, The Hague.

Gewirth, A. (1995) 'Rights', in The Oxford Companion to Philosophy, Oxford Univ. Press, Oxford.

Goldewijk, B.K., and Fortman, B. de G. (1999) Where Needs Meet Rights. WCC Publications, Geneva.

Green, R.H. (1976) 'Basic Human Needs', IDS Bulletin, 9(4), pp. 7-11.

Hampson, F.O., et al. (2002) Madness in the Multitude: Human Security and World Disorder, Oxford University Press, Ottawa.

Hanlon, J. (2000) 'How Much Debt Must be Cancelled?', Journal. of International Development, 12, pp. 877901.

Haq, M. ul (1999) Reflections on Human Development. Expanded edition. Oxford Univ. Press, Delhi.

Harvard [Harvard Human Security Project] (2002) Definitions of Human Security, http://www.hsph.harvard.edu/hpcr/events/hsworkshop/list_definitions.pdf

Hubert, D. (2004) 'An Idea that Works in Practice', Security Dialogue, 25(3), pp. 351-2.

ILO (1976), Employment, Growth and Basic Needs, Geneva, International Labour Office.

Japan, Govt. of (1999) Diplomatic Bluebook 1999, Tokyo: Ministry of Foreign Affairs.

Leaning, J. (2004) 'Psychosocial Well-Being over Time', Security Dialogue, 25(3), pp.354-5.

Maslow, A. (1943) ‘A Theory of Human Motivation', Psychology Review, 50, pp. 370-96.

Mitchell, C. (ed.) (2001) Special issue in honor of John W. Burton, International Journal of Peace Studies, $6(1)$.

Nussbaum, M. (1997) Cultivating Humanity, Harvard Univ. Press, Cambridge, MA. 
Nussbaum, M. (2000) Women and Human Development: the capabilities approach, Cambridge Univ. Press, Cambridge.

O’Neill, O., (1996) Towards Justice and Virtue. Cambridge Univ. Press, Cambridge.

Owen, T., 'Human Security - Conflict, Critique and Consensus', Security Dialogue, 35(3), pp. 373-387.

Penz, P. (1991) 'The Priority of Basic Needs', in K. Aman ed., Ethical Principles for Development: Needs, Capacities or Rights, Montclair State University, Upper Montclair, NJ.

Ramphele, M. (2004) Reply, Seminar at the National Council for Research on Women, Washington DC, March 11. www.ncrw.org/interest/bernstein_remarks.htm

Robinson, M. (2003) 'Protection and Empowerment: Connecting Human Rights and Human Security', http://www.oxan.com/about/news/2003-09-18.

Sen, A. (2003) ‘Human Security Now', Soka Gakkai International Quarterly, July 2003.

Shue, H. (1980) Basic Rights, Princeton Univ. Press, Princeton.

Smith, D.M. (2000) 'Human rights', in The Dictionary of Human Geography, $4^{\text {th }}$ edition, edited by R.J. Johnston et al., Blackwell, Oxford.

St. Clair, A.L. (2004a) 'The role of ideas in the United Nations Development Programme', in Morten Bøås and Desmond McNeill (eds) Global institutions and development : framing the world?, Routledge, London.

---- (2004b) Poverty Conceptions in the UNDP and the World Bank: Knowledge, Ethics and Politics.: Department of Sociology, University of Bergen.

Star, S., and Griesemer, J. (1989) 'Institutional ecology, "translations" and boundary objects', Social Studies of Science, 19, 387-420.

Thakur, R. (2004) “A political worldview', Security Dialogue 35(3), 347-8.

Thomas, C. (2000) Global Governance, Development and Human Security, Pluto, London.

---- (2004) 'A Bridge Between the Interconnected Challenges Confronting the World', Security Dialogue, 35(3), 353-4.

UNDP (1990-) Human Development Report (annual), Oxford Univ. Press, New York.

Uvin, P. (2004), 'A Field of Overlaps and Interactions', 35(3), Security Dialogue, 352-3.

Waldron, J. (1993) 'Rights', in A Companion to Contemporary Political Philosophy, eds. R. Goodin \& P. Pettit, Blackwell, Oxford.

\footnotetext{
${ }^{1}$ Or: 'Human security is not a concern with weapons. It is a concern with human dignity.' (Haq, 1999, p. 116)

${ }^{2}$ Strictly speaking, HD does not concern expansion of all capabilities, but of those capabilities which people have (good) reason to value. The unqualified formulation is widespread, despite the reality that many capabilities are undesirable. In Alkire's basic-needs-focused formulation, security does require equity, at the level of basics.

${ }^{3}$ In the phrase 'freedom from want', 'want' originally had the older sense of non-fulfilment of a basic need. If it is given the modern sense, 'desire', then freedom may be attained by the Buddhist path: not by wantfulfilment but by elimination of desire. Behind that elimination may lie 'liberation' from the self, as supposedly an illusion or trap. I treat that path to security as an attempt to transcend human-ness rather than secure it, and as outside the HS field.

${ }^{4}$ If HS is defined in terms of stability, and maintaining or restoring it, then it includes emergency relief, whereas HD is defined partly in terms of 'more durable change' (Alkire, p. 2003, p. 37).

${ }^{5}$ Note also the expansive definition by the UN University's Vice Rector for Peace and Security: 'Human security refers to the quality of life of the people of a society or polity' (Thakur, 1997, pp. 53-4 [cited in Harvard, 2002]); here human security means securing goods, with emphasis on how much is secured. Recently, he defined HS as protection against 'critical life-threatening dangers' (Thakur, 2004), which is closer to a basic needs definition (the dangers include not only physical violence).

${ }^{6}$ Defined in terms of all the forces 'to threaten human lives, livelihoods and dignity' (Govt. of Japan, 1999, as cited in Harvard, 2002, p.5).

${ }^{7}$ Alkire omits the word 'material' between 'basic' and 'needs' in both of the following passages: 'The change from development aimed at relieving material poverty and providing for basic needs to development aimed at "giving people choices" also came about in response of the impetus to highlight the
} 
importance of dignity, esteem and other non-material aspects of life. ... Indeed some non-material values (such as cultural practice or identity) seem at times to displace basic needs (such as housing) altogether' (Alkire, 2003, p. 35). Dignity, esteem and non-material aspects of life have been central, and explicitly so, in Basic Human Needs work (see e.g. Green, 1976).

${ }^{8}$ Besides 'human rights', 'basic human needs', 'human development' and 'human security', the family of 'human' concepts includes 'human decency' and 'human dignity'. They are not investigated in this paper.

${ }^{9}$ This is a broader usage than that cited by Smith (2000, p. 360), who specifies 'security oriented rights (or claim rights) which refer more to economic and social requirements to protect people's physical and material status, such as unemployment and social security benefits'.

${ }^{10}$ UNDP's currrent work with the central and state governments in India to apply human development ideas and realize the MDGs is a major example.

11 'What do we mean by security? We mean, in its most simple expression, all those things that men and women anywhere in the worl d cherish most', said a Deputy Secretary-General of the UN (Louise Frechette 1999, cited in Harvard, 2002). '..."security" is the label given to the highest priority issues' (Owen, 2004, p. 379). 